\title{
CORRIGENDUM
}

\section{Effect of fungicides used for powdery mildew disease management on African weaver ant Oecophylla longinoda (Hymenoptera: Formicidae), a biocontrol agent of sap-sucking pests in cashew crop in Tanzania}

\author{
Moses I. Olotu, Nguya K. Maniania, Sunday Ekesi, \\ Zuberi S. Seguni and Hannalene du Plessis
}

doi:10.1017/S1742758413000313, Published by Cambridge University Press, 9 October 2013.

In the article above the accepted date was incorrect. The correct date is 11 September 2013.

\section{Reference}

Olotu M. I., Maniania N. K., Ekesi S., Segunia Z. S. and du Plessis H. (2013) Effect of fungicides used for powdery mildew disease management on African weaver ant Oecophylla longinoda (Hymenoptera: Formicidae), a biocontrol agent of sap-sucking pests in cashew crop in Tanzania. International Journal of Tropical Insect Science. Published by Cambridge University Press, 9 October 2013. doi:10.1017/S1742758413000313. 